\title{
Biochemical and genetic analyses of the oomycete Pythium insidiosum provide new insights into clinical identification and urease-based evolution of metabolism-related traits
}

\author{
Theerapong Krajaejun Corresp., ${ }^{1}$, Thidarat Rujirawat ${ }^{2,3}$, Teerat Kanpanleuk ${ }^{1}$, Pitak Santanirand ${ }^{1}$, Tassanee \\ Lohnoo $^{2}$, Wanta Yingyong ${ }^{2}$, Yothin Kumsang ${ }^{2}$, Pattarana Sae-Chew ${ }^{2}$, Weerayuth Kittichotirat ${ }^{4}$, Preecha \\ Patumcharoenpol ${ }^{4}$ \\ 1 Department of Pathology, Ramathibodi Hospital, Mahidol University, Bangkok, Thailand \\ 2 Research Center, Faculty of Medicine, Ramathibodi Hospital, Mahidol University, Bangkok, Thailand \\ 3 Molecular Medicine Program, Multidisciplinary Unit, Faculty of Science, Mahidol University, Bangkok, Thailand \\ 4 Systems Biology and Bioinformatics Research Group, Pilot Plant Development and Training Institute, King Mongkut's University of Technology Thonburi, \\ Bangkok, Thailand \\ Corresponding Author: Theerapong Krajaejun \\ Email address: mr_en@hotmail.com
}

The oomycete microorganism, Pythium insidiosum, causes the life-threatening infectious condition, pythiosis, in humans and animals worldwide. Affected individuals typically endure surgical removal of the infected organ(s). Detection of $P$. insidiosum by the established microbiological, immunological or molecular methods is not feasible in nonreference laboratories, resulting in delayed diagnosis. Biochemical assays have been used to characterize $P$. insidiosum, some of which could aid in the clinical identification of this organism. Although hydrolysis of maltose and sucrose has been proposed as the key biochemical feature useful in discriminating $P$. insidiosum from other oomycetes and fungi, this technique requires a more rigorous evaluation involving a wider selection of $P$. insidiosum strains. Here, we evaluated ten routinely-available biochemical assays for characterization of $26 P$. insidiosum strains, isolated from different hosts and geographic origins. Initial assessment revealed diverse biochemical characteristics across the $P$. insidiosum strains tested. Failure to hydrolyze sugars is observed, especially in slowgrowing strains. Because hydrolysis of maltose and sucrose varied among different strains, use of the biochemical assays for identification of $P$. insidiosum should be cautioned. The ability of $P$. insidiosum to hydrolyze urea is our focus, because this metabolic process relies on the enzyme urease, an important virulence factor of other pathogens. The ability to hydrolyze urea varied among $P$. insidiosum strains and was not associated with growth rates. Genome analyses demonstrated that urease- and urease accessory proteinencoding genes are present in both urea-hydrolyzing and non-urea-hydrolyzing strains of $P$. insidiosum. Urease genes are phylogenetically-conserved in $P$. insidiosum and related oomycetes, while the presence of urease accessory protein-encoding genes is markedly- 
diverse in these organisms. In summary, we dissected biochemical characteristics and drew new insights into clinical identification and urease-related evolution of $P$. insidiosum. 
1 Biochemical and genetic analyses of the oomycete Pythium insidiosum provide new insights

2 into clinical identification and urease-based evolution of metabolism-related traits

3

4 Theerapong Krajaejun ${ }^{1}$, Thidarat Rujirawat ${ }^{2,3}$, Teerat Kanpanleuk ${ }^{1}$, Pitak Santanirand ${ }^{1}$, Tassanee

5 Lohnoo $^{2}$, Wanta Yingyong ${ }^{2}$, Yothin Kumsang ${ }^{2}$, Pattarana Sae-Chew ${ }^{2}$, Weerayuth Kittichotirat ${ }^{4}$,

6 Preecha Patumcharoenpol ${ }^{4}$

7

$8{ }^{1}$ Department of Pathology, Faculty of Medicine, Ramathibodi Hospital, Mahidol University,

9 Bangkok, Thailand

$10{ }^{2}$ Research Center, Faculty of Medicine, Ramathibodi Hospital, Mahidol University, Bangkok,

11 Thailand

$12{ }^{3}$ Molecular Medicine Program, Multidisciplinary Unit, Faculty of Science, Mahidol, Bangkok,

13 Thailand

$14{ }^{4}$ Systems Biology and Bioinformatics Research Group, Pilot Plant Development and Training

15 Institute, King Mongkut's University of Technology Thonburi, Bangkok, Thailand

16

17 Corresponding author:

18 Theerapong Krajaejun ${ }^{1}$

19 Department of Pathology, Faculty of Medicine, Ramathibodi Hospital, Mahidol University

20 270, Rama 6 Road, Bangkok, 10400, Thailand.

21 Email address: mr_en@hotmail.com 


\section{Abstract}

23 The oomycete microorganism, Pythium insidiosum, causes the life-threatening infectious

24 condition, pythiosis, in humans and animals worldwide. Affected individuals typically endure

25 surgical removal of the infected organ(s). Detection of $P$. insidiosum by the established

26 microbiological, immunological or molecular methods is not feasible in non-reference

27 laboratories, resulting in delayed diagnosis. Biochemical assays have been used to characterize

28 P. insidiosum, some of which could aid in the clinical identification of this organism. Although

29 hydrolysis of maltose and sucrose has been proposed as the key biochemical feature useful in

30 discriminating $P$. insidiosum from other oomycetes and fungi, this technique requires a more

31 rigorous evaluation involving a wider selection of $P$. insidiosum strains. Here, we evaluated ten

32 routinely-available biochemical assays for characterization of $26 P$. insidiosum strains, isolated

33 from different hosts and geographic origins. Initial assessment revealed diverse biochemical

34 characteristics across the $P$. insidiosum strains tested. Failure to hydrolyze sugars is observed,

35 especially in slow-growing strains. Because hydrolysis of maltose and sucrose varied among

36 different strains, use of the biochemical assays for identification of $P$. insidiosum should be

37 cautioned. The ability of $P$. insidiosum to hydrolyze urea is our focus, because this metabolic

38 process relies on the enzyme urease, an important virulence factor of other pathogens. The ability

39 to hydrolyze urea varied among $P$. insidiosum strains and was not associated with growth rates.

40 Genome analyses demonstrated that urease- and urease accessory protein-encoding genes are

41 present in both urea-hydrolyzing and non-urea-hydrolyzing strains of $P$. insidiosum. Urease

42 genes are phylogenetically-conserved in P. insidiosum and related oomycetes, while the presence

43 of urease accessory protein-encoding genes is markedly-diverse in these organisms. In summary, 
44 we dissected biochemical characteristics and drew new insights into clinical identification and 45 urease-related evolution of $P$. insidiosum.

46

47 


\section{Introduction}

50

51

52 53

54 55

56

57

Infectious diseases pose a greater threat to humans, animals and plants as drug-resistant varieties emerge. Among these is pythiosis (the infectious condition caused by the fungus-like, highly-invasive, oomycete microorganism Pythium insidiosum), which has been increasingly reported in tropical and subtropical countries (Thianprasit, Chaiprasert \& Imwidthaya, 1996;

4 Krajaejun et al., 2006b; Gaastra et al., 2010). Many healthcare personnel are not familiar with pythiosis. The use of anti-fungal drugs to control this pathogen has generally been ineffective (Lerksuthirat et al., 2017). Affected individuals often undergo surgical removal of the infected organ, and many succumb to the progressive disease (Krajaejun et al., 2004, 2006b). Early and accurate diagnosis is necessary to ensure prompt and proper treatment, and thus an improved clinical outcome for patients. Isolation of the pathogen from infected tissues by the standard microbiological procedure is time-consuming and requires experience (Chaiprasert et al., 1990). A number of detection tools such as serological tests (Pracharktam et al., 1991; Krajaejun et al., 2002; Grooters et al., 2002; Krajaejun et al., 2006a, 2009; Jindayok et al., 2009; Supabandhu et al., 2009; Chareonsirisuthigul et al., 2013; Keeratijarut et al., 2013; Intaramat et al., 2016), immunostaining assays (Keeratijarut et al., 2009; Inkomlue et al., 2016), and molecular biology methods (Grooters \& Gee, 2002; Botton et al., 2011; Keeratijarut et al., 2014, 2015; Rujirawat et al., 2017), have been successfully developed for $P$. insidiosum infection. However, such tools are not generally available in non-reference clinical laboratories, resulting in missed or delayed diagnosis of pythiosis.

9 Biochemical assays may be used to characterize $P$. insidiosum and could aid in the

70 clinical identification of this organism. Different patterns of enzymatic activities in phosphatases,

1 esterases, lipases, glucosidases, and proteases have been observed among strains of $P$. insidiosum 
72 (Davis et al., 2006; Zanette et al., 2013). Recently, Vilela and co-workers adopted an array of

73 biochemical assays (hydrolysis of sugars, citrate, urea, esculin, etc.) to differentiate the

74 pathogenic oomycetes, including six strains of $P$. insidiosum (Vilela, Viswanathan \& Mendoza,

75 2015). They proposed that an ability to hydrolyze maltose and sucrose is a key biochemical

76 feature to discriminate $P$. insidiosum from other mammalian-pathogenic oomycetes (i.e.,

77 Lagenidium species) and morphologically-similar fungi. Although the use of these biochemical

78 assays in the clinical identification of $P$. insidiosum is promising, it requires further evaluation

79 with a more extensive selection of $P$. insidiosum strains.

80 In the current study, we evaluated ten routinely-available biochemical assays for

81 characterization of 26 phylogenetically-defined strains of $P$. insidiosum. The strains tested had

82 different geographic origins (i.e., Clade-I strains from Americas, Clade-II strains from Asia and

83 Australia, and Clade-III mostly from Thailand) and were isolated from different hosts (i.e.,

84 humans and horses) (Schurko et al., 2003; Chaiprasert et al., 2009; Rujirawat et al., 2017). Initial

85 assessment revealed strain to strain variation amongst the strains of $P$. insidiosum tested. The

86 capacity to hydrolyze urea became our focus because this metabolic process relies on the enzyme

87 urease, an important virulence factor of Helicobacter pylori and Cryptococcus neoformans (Cox

88 et al., 2000; Rutherford, 2014; Mora \& Arioli, 2014). Since the genome of $P$. insidiosum is

89 publically available (Rujirawat et al., 2015), we were able to explore the genetic and

90 evolutionary details of the urease gene in P. insidiosum and related oomycetes.

91

92

93 


\section{Materials \& methods}

95 Ethics statement

This study was approved by the Committee on Human Rights Related to Research

97 Involving Human Subjects, at the Faculty of Medicine, Ramathibodi Hospital, Mahidol

98 University (approval number ID 05-60-77).

99

100

101

102

103

104

105

106

107

108

109

110

111

112

113

114

115

116

\section{Microorganisms and growths}

Twenty-six strains of $P$. insidiosum isolated from humans $(n=14)$ or equines $(n=10)$ with pythiosis and from the environment $(n=2)$, were available for this study (Table 1). Identity and genotyping (i.e., Clade-I, II, and III) of $P$. insidiosum were confirmed through culture identification, single nucleotide polymorphism-based multiplex PCR, and rDNA sequence analysis (Chaiprasert et al., 1990; Badenoch et al., 2001; Chaiprasert et al., 2009; Rujirawat et al., 2017). Because $P$. insidiosum has been classified as a Biosafety Level 2 organism (https://www.atcc.org), Biosafety Level 2 precautions were followed throughout this study (https://www.cdc.gov/biosafety). All of the organisms were retrieved from stock cultures, and maintained on Sabouraud dextrose (SD) agar at $37^{\circ} \mathrm{C}$ for at least three passages. SD agar plugs ( $5 \mathrm{~mm}$ in diameter) from one-week-old, actively-growing cultures of $P$. insidiosum were then prepared (Krajaejun et al., 2010; Lerksuthirat et al., 2017) for biochemical assays. Radial growth rate ( $\mathrm{mm} /$ day) of $P$. insidiosum was evaluated, using the previously-described method (Krajaejun et al., 2010; Lerksuthirat et al., 2017). Strains with growth rates $\geq 5 \mathrm{~mm} /$ day were defined as fast-growing strains, while the rest were defined as slow-growing strains.

\section{Biochemical assays}


118 in test tubes (except the DNase assay agar, which was prepared in a Petri dish), using ingredients

119 purchased from BD Difco and BBL (if not stated otherwise), and the recommended protocols of

120 the manufacturers. These agars included: urea agar (urease assay), Simmons'citrate agar (citrate

121 hydrolysis assay), bile esculin agar (esculin hydrolysis assay), DNA agar (DNase assay), and

122 purple agar base (sugar hydrolysis assay) with $2 \%(\mathrm{wt} / \mathrm{v})$ dextrose, lactose, maltose, sucrose

123 (Merck), trehalose (Sigma) or xylose. A 5-mm diameter agar plug of an actively-growing colony

124 of each $P$. insidiosum strain was placed upon each type of agar and incubated at $37^{\circ} \mathrm{C}$ for 2 days

125 before biochemical reactions were read. Each biochemical assay was interpreted as 'negative' if

126 the agar color remained unchanged, and interpreted as 'positive' when the agar color changed: (i)

127 from yellow to pink (urease assay); (ii) from brown to black (esculin hydrolysis assay); (iii) from

128 green to blue (citrate hydrolysis assay); (iv) from dark blue to yellow (all sugar hydrolysis

129 assays); and (v) from blue to colorless (DNase assay). All biochemical assays were performed in 130 duplicate.

131

132 Identification of urease- and urease accessory protein-encoding genes

133 The Oomycete Gene Table is an online comparative genomic analysis tool, derived from 134 sequence similarity-based gene grouping of the genome sequences of $P$. insidiosum, 19 related 135 oomycetes, and two diatoms (Table S1) (Kittichotirat et al., 2011; Rujirawat et al., 2018). In the 136 current study, the Oomycete Gene Table shows identification of putative urease- and urease 137 accessory protein-encoding genes in the genomes of the oomycetes and diatoms (Figure 1).

138 Predicted urease protein sequences of the oomycetes and diatoms were aligned using MUSCLE 
139 (Edgar, 2004; Dereeper et al., 2008, 2010), and assessed for sequence identity and similarity

140 using NCBI BLAST (https://blast.ncbi.nlm.nih.gov/).

141 The urease and urease accessory protein sequences of the plant Arabidopsis thaliana

142 [accession numbers: NP_176922 (urease structure protein, URE); NP_850239 (urease accessory

143 protein D, URED); NP_173602 (urease accessory protein F, UREF); and NP_180994 (urease

144 accessory protein G, UREG)] (Witte, Rosso \& Romeis, 2005) were retrieved from the NCBI

145 database. To assess the presence of the orthologs in P. insidiosum, all of these Arabidopsis

146 proteins were TBLASTN searched against the genome of the P. insidiosum strain Pi35 (also

147 known as Pi-S), and two Illumina-derived genomes of the P. insidiosum strains Pi07 (also known

148 as CBS 573.85) and Pi45 (Rujirawat et al., 2015; Kittichotirat et al., 2017; Patumcharoenpol et

149 al., 2018), using the locally-installed blast 2.2.28+ program (http://www.ncbi.nlm.nih.gov/) and 150 the cut-off $E$-value $\leq 10^{-6}$.

151

152 Phylogenetic analysis

153

Phylogenetic analysis of 24 urease-encoding sequences from P. insidiosum (strains Pi07,

154 Pi35, and Pi45), related oomycetes, and diatoms (outgroup) (Table S1) was executed online at

155 www.phylogeny.fr (Dereeper et al., 2008). In brief, the sequence alignment was performed by

156 MUSCLE (Edgar, 2004). Poorly-aligned positions or gaps were eliminated by Gblocks

157 (Castresana, 2000). Phylogenetic relationships were calculated by PhyML, using the maximum-

158 likelihood algorithm and the branch-assessing aLRT test (Anisimova \& Gascuel, 2006; Guindon

159 et al., 2010). The phylogenetic tree was reconstructed using TreeDyn (Chevenet et al., 2006).

160

161 Sequence accession numbers 
162 Sequences of the putative urease genes of $P$. insidiosum identified in the genomes of $P$.

163 insidiosum strains Pi35 (accession number, LC317047 for Ure 1), Pi07 (accession number

164 LC325168 for Ure 1), and Pi45 (LC325169 for Ure1A, and LC325170 for Ure 1B) have been

165 submitted to the DDBJ database.

166 


\section{Results}

168 Growth and biochemical characteristics of $P$. insidiosum

169

Twenty-six strains of $P$. insidiosum included in the current study were derived from

170 different sources (humans, $\mathrm{n}=14$; animals, $\mathrm{n}=10$; and the environment, $\mathrm{n}=2$ ) and geographic

171 origins (Asia, $\mathrm{n}=15$; Americas, $\mathrm{n}=10$; and Australia, $\mathrm{n}=1$ ). Based on the growth rates, $P$.

172 insidiosum can be divided into two groups: (i) fast-growing strains (growth rate $\geq 5 \mathrm{~mm} /$ day;

$173 \mathrm{n}=17 ; 65 \%$ of all strains), and (ii) slow-growing strains (growth rate $<5 \mathrm{~mm} / \mathrm{day} ; \mathrm{n}=9 ; 35 \%$ of

174 all strains) (Table 1). Each group contained representatives from all phylogenetically-distinct

175 Clades (-I, -II, and -III), and from both humans and animals. Both environmental strains

176 belonged to the fast-growing group.

177 As summarized in Table 1, all strains of $P$. insidiosum hydrolyzed esculin in the presence 178 of bile but failed to breakdown citrate and two sugars (i.e., lactose and xylose). The majority of 179 the strains can hydrolyze dextrose ( $n=22 ; 85 \%$ of all strains), maltose $(n=22 ; 85 \%)$, sucrose $180(n=20 ; 77 \%)$, trehalose $(n=22 ; 85 \%)$, and DNA $(n=23 ; 89 \%)$, while those that cannot utilize

181 these substrates were almost all slow-growing. Unlike the other fast-growing strains, Pi03 did 182 not hydrolyze sucrose. With regard to the urease assay, $71 \%(\mathrm{n}=12)$ of the fast-growing and $78 \%$ $183(\mathrm{n}=7)$ of the slow-growing strains could catabolize urea. Biochemical characteristics of some 184 representative strains at day 0 (all agar colors remained unchanged) and day 2 post-inoculation 185 (all biochemical reactions were read) were displayed in Figure 2.

Ureases and urease accessory proteins of $\boldsymbol{P}$. insidiosum and related oomycetes

Urease requires a number of urease accessory proteins to mediate enzymatic activity.

189 Genes annotated as 'urease' or 'urease accessory protein' were searched using the Oomycete 
190 Gene Table (Rujirawat et al., 2018). All oomycetes and diatoms harbored a single copy of

191 urease-encoding sequence (Gene cluster ID, \#057948; average protein length: 849 amino acids;

192 range: 761-1,345 amino acids), except the oomycete $A$. invadans, which contained three copies

193 of this gene (Figure 1; Table S1). Protein sequence alignment showed a high degree of identity

194 (59-81\%) and similarity (72-88\%) between the ureases of oomycetes and diatoms (Figure 3;

195 Table S1).

196 A total of eight clusters of urease accessory protein-encoding genes were differentially

197 presented in the genomes of 20 oomycetes (Figure 1). These gene clusters included Cluster IDs:

198 \#051204 (found in 19 species), \#291367 (17 species), \#181024 (16 species), \#152345 (15

199 species), \#205644 (13 species), \#213938 (12 species), \#122775 (10 species), and \#007410 (5

200 species). Each oomycete genus possessed a different number of urease accessory gene clusters,

201 for example: 7-8 clusters in Phytophthora, 5-8 in Pythium, 7 in Phytopythium, 4 in Saprolegnia,

202 1-3 in Aphanomyces, and one each in Albugo and Hyaloperonospora. None of these urease

203 accessory gene clusters was identified in the diatom genomes.

204 TBLASTN search of the function-verified urease URE and urease accessory proteins

205 URED, UREF and UREG of the plant $A$. thaliana showed significant matches $(E$-value $\leq-6)$ in

206 the genomes of three representative P. insidiosum strains (Table 2): Pi07 (Clade-I strain), Pi35

207 (Clade-II strain), and Pi45 (Clade-III strain). One exception is UREF, which failed to find match 208 in the genome of strain Pi07.

209

210 Urease-based phylogenetic relationships

211 A set of 24 urease-encoding sequences identified in the genomes of Pythium insidiosum,

212 related oomycetes, and diatoms (Figure 1; Table S1), were subjected to reconstruction of a 
213 maximum likelihood-based phylogenetic tree. As expected, phylogenetic locations of the ureases

214 of the diatoms (serving as an outgroup) were separated from that of the oomycetes. The

215 oomycete ureases were allocated into three phylogenetically-distinct clades (Figure 4): (i) the

216 clade of Pythium, Phytophthora, Phytopythium and Hyaloperonospora species; (ii) the clade of

217 Aphanomyces and Saprolegnia species; and (iii) the clade of Albugo species. Most of the

218 organisms contain one copy of the urease-encoding gene, except $A$. invadans (three copies) and

219 P. insidiosum strain Pi45 (two copies). Four urease-encoding sequences from the $P$. insidiosum

220 strains Pi07, Pi35, and Pi45 were grouped together, and placed more proximally to non-

221 insidiosum Pythium, Phytophthora, Phytopythium and Hyaloperonospora species than to other

222 oomycete species.

223 


\section{Discussion}

225

A capacity to hydrolyze esculin, but not citrate, lactose and xylose, was the shared

226 biochemical characteristic found in all 26 strains of $P$. insidiosum (Table 1), consistent with the

227 observations of Vilela and co-workers (Vilela, Viswanathan \& Mendoza, 2015). The enzymatic

228 components necessary to hydrolyze urea and certain sugars (i.e., dextrose, maltose, sucrose and

229 trehalose) were found in some strains but were not ubiquitous (Table 1). This finding contrasts

230 with reports by Vilela et al., who showed all six $P$. insidiosum strains tested [including the

231 strains CBS 574.85 and ATCC 28251 of the current study] could utilize urea and these sugars.

232 This is especially important considering maltose and sucrose are two key sugars that were

233 thought to differentiate $P$. insidosum from other pathogenic oomycetes and fungi (Vilela,

234 Viswanathan \& Mendoza, 2015). Failure to breakdown these sugars, in some strains, was

235 markedly associated with slow-growth (growth rate, $<5 \mathrm{~mm} /$ day) in $P$. insidiosum (Table 1).

236 Because the biochemical characteristics varied among different strains (and even between

237 different cultures of the same strain), caution is advised for the use of tests for the hydrolysis of

238 maltose and sucrose in the clinical identification of $P$. insidiosum (especially for slow-growing

239 strains).

240 Unlike the hydrolysis of sugars and DNA, the ability to utilize urea was not associated

241 with growth rate in P. insidiosum. Efficient breakdown of urea can be observed in many slow-

242 growing strains (i.e., Pi04, Pi07, Pi20, Pi44, Pi46, Pi48, and CBS 574.85), and not in all fast-

243 growing strains (i.e., Pi23, Pi45, Pi49, Pi51, and ATCC 28251) (Table 1). The inability to utilize

244 urea in a number of $P$. insidiosum strains could correspond to the lack of the urease-encoding

245 gene, Ure1, in their genomes. We investigated the presence of Ure 1 in the genomes of three

246 representative strains of $P$. insidiosum, which included: (i) the urea-hydrolyzing, slow-growing, 
247 Clade-I strain Pi07; (ii) the urea-hydrolyzing, fast-growing, Clade-II strain Pi35; and (iii) the

248 non-urea-hydrolyzing, fast-growing, Clade-III strain Pi45. All three strains contain Ure 1

249 orthologous sequence, which significantly matched the plant Arabidopsis urease (URE)

250 (algorithm, TBLASTN; $E$-value, 0.0; identity, 63-64\%; similarity, 73-76\%; Table 2).

251 Surprisingly, the non-urea-hydrolyzing strain Pi45 harbors two copies of Ure1 (designated as

252 Ure 1A and Ure 1B), suggesting that the presence of Ure 1 genes in the genome is not necessarily

253 associated with the ability to hydrolyze urea in P. insidiosum.

254 In plants and microbes, urease accessory proteins [i.e., UreE, UreF, UreG and UreD

255 (orthologous to UreH)] are necessary for maturation and activation of the nickel-containing

256 metalloenzyme urease (Witte, Rosso \& Romeis, 2005; Fong et al., 2013). The urease structure

257 protein (URE) and several accessory proteins (URED, UREF and UREG) are required for

258 enzymatic activity of the Arabidopsis urease (Witte, Rosso \& Romeis, 2005). In addition to

259 urease, we also sought evidence of urease accessory protein-encoding genes in P. insidiosum.

260 TBLASTN search showed the URED, UREF and UREG orthologs in the genomes of $P$.

261 insidiosum strains Pi07, Pi35, and Pi45, as summarized in Table 2. A UREF ortholog was not

262 found in the urea-hydrolyzing strain Pi07 (this may be due to the incompleteness of its genome),

263 but URED and UREG orthologs were. Unlike the other strains, the non-urea-hydrolyzing strain

264 Pi45 has two copies of both urease and urease accessory genes (Table 2). Since $P$. insidiosum

265 generally contains a complete set of urease- and accessory protein-coding sequences, failure to

266 utilize urea in some strains (Table 1) may be due to limited expression and/or down-regulation

267 of these genes.

268 Genome analyses demonstrated that urease- and accessory protein-encoding genes are

269 conserved in P. insidiosum from all three phylogenetically-distinct clades, although gene 
270 duplication could occur in some strains (Table 2). We used the identified urease-encoding genes

271 to further investigate metabolism-related evolution in P. insidiosum, non-human-pathogenic

272 oomycetes, and diatoms (outgroup) (Table S1). The ureases are highly-conserved in all

273 organisms (Figure 3), and their phylogenetic relationships are allocated as expected in the

274 reconstructed tree (Figure 4). However, the presence of urease accessory protein-encoding genes

275 is diverse in these organisms (Figure 1), ranging from: (i) harboring a wide variety of these

276 genes in the genera Phytophthora, Pythium and Phytopythium; to (ii) containing just a few genes

277 in the genera Hyaloperonospora, Albugo, Aphanomyces and Saprolegnia.

278

279 Conclusions

280 No unique biochemical characteristic is observed among different strains of $P$.

281 insidiosum, cautioning the use of related biochemical assays for pathogen identification. Unlike

282 the hydrolysis of sugars, the ability to hydrolyze urea was not associated with $P$. insidiosum

283 growth, as many slow-growing strains, and not all fast-growing strains, can utilize urea, even

284 though the urease- and accessory protein-encoding genes are present and highly-conserved in

285 both urea-hydrolyzing and non-hydrolyzing strains of $P$. insidiosum. Future investigations on

286 expression and regulation of the urease and accessory protein-encoding genes could elaborate the

287 urea metabolism and its potential role in pathogenicity in P. insidiosum. Gain and loss of urease

288 and accessory protein-encoding genes occurred in the genomes of oomycetes and diatoms as

289 their evolutions diverged. In the current study, we dissected several biochemical characteristics,

290 and provided new insights into urease-based evolution of $P$. insidiosum.

291 


\section{Acknowledgements}

293 We thank Dr. Tristan Brandhorst and Dr. Thomas D. Sullivan for reviewing the 294 manuscript and making valuable suggestions.

295 


\section{References}

297 Anisimova M., Gascuel O. 2006. Approximate likelihood-ratio test for branches: A fast,

298

299 accurate, and powerful alternative. Systematic Biology 55:539-552. DOI:

$10.1080 / 10635150600755453$.

300

301

302

303

304

305

306

307

308

309

310

311

312

313

314

315

316

317

318

Badenoch PR., Coster DJ., Wetherall BL., Brettig HT., Rozenbilds MA., Drenth A., Wagels G. 2001. Pythium insidiosum keratitis confirmed by DNA sequence analysis. The British Journal of Ophthalmology 85:502-503.

Botton SA., Pereira DIB., Costa MM., Azevedo MI., Argenta JS., Jesus FPK., Alves SH., Santurio JM. 2011. Identification of Pythium insidiosum by nested PCR in cutaneous lesions of Brazilian horses and rabbits. Current Microbiology 62:1225-1229. DOI: 10.1007/s00284-010-9781-4.

Castresana J. 2000. Selection of conserved blocks from multiple alignments for their use in phylogenetic analysis. Molecular biology and evolution 17:540-552.

Chaiprasert A., Krajaejun T., Pannanusorn S., Prariyachatigul C., Wanachiwanawin W., Sathapatayavongs B., Juthayothin T., Smittipat N., Vanittanakom N., Chindamporn A. 2009. Pythium insidiosum Thai isolates: molecular phylogenetic analysis. Asian Biomedicine 3:623-633.

Chaiprasert A., Samerpitak K., Wanachiwanawin W., Thasnakorn P. 1990. Induction of zoospore formation in Thai isolates of Pythium insidiosum. Mycoses 33:317-323.

Chareonsirisuthigul T., Khositnithikul R., Intaramat A., Inkomlue R., Sriwanichrak K., Piromsontikorn S., Kitiwanwanich S., Lowhnoo T., Yingyong W., Chaiprasert A., Banyong R., Ratanabanangkoon K., Brandhorst TT., Krajaejun T. 2013. Performance comparison of immunodiffusion, enzyme-linked immunosorbent assay, 
immunochromatography and hemagglutination for serodiagnosis of human pythiosis.

320 Diagnostic Microbiology and Infectious Disease 76:42-45. DOI:

321 10.1016/j.diagmicrobio.2013.02.025.

322 Chevenet F., Brun C., Bañuls A-L., Jacq B., Christen R. 2006. TreeDyn: towards dynamic 323 graphics and annotations for analyses of trees. BMC Bioinformatics 7:439. DOI: $10.1186 / 1471-2105-7-439$.

325

Cox GM., Mukherjee J., Cole GT., Casadevall A., Perfect JR. 2000. Urease as a virulence factor 326 in experimental cryptococcosis. Infection and Immunity 68:443-448.

327

328

329

330

331

332

333

334

335

336

337

338

339

340

341

Davis DJ., Lanter K., Makselan S., Bonati C., Asbrock P., Ravishankar JP., Money NP. 2006. Relationship between temperature optima and secreted protease activities of three Pythium species and pathogenicity toward plant and animal hosts. Mycological Research 110:96-103. DOI: 10.1016/j.mycres.2005.08.009.

Dereeper A., Audic S., Claverie J-M., Blanc G. 2010. BLAST-EXPLORER helps you building datasets for phylogenetic analysis. BMC evolutionary biology 10:8. DOI: 10.1186/14712148-10-8.

Dereeper A., Guignon V., Blanc G., Audic S., Buffet S., Chevenet F., Dufayard J-F., Guindon S., Lefort V., Lescot M., Claverie J-M., Gascuel O. 2008. Phylogeny.fr: robust phylogenetic analysis for the non-specialist. Nucleic Acids Research 36:W465-469. DOI: 10.1093/nar/gkn180.

Edgar RC. 2004. MUSCLE: multiple sequence alignment with high accuracy and high throughput. Nucleic Acids Research 32:1792-1797. DOI: 10.1093/nar/gkh340.

Fong YH., Wong HC., Yuen MH., Lau PH., Chen YW., Wong K-B. 2013. Structure of UreG/UreF/UreH complex reveals how urease accessory proteins facilitate maturation of 
Helicobacter pylori urease. PLoS biology 11:e1001678. DOI:

344 Gaastra W., Lipman LJA., De Cock AWAM., Exel TK., Pegge RBG., Scheurwater J., Vilela R.,

345

346

347

348

349

350

351

352

353

354

355

356

357

358

359

360

361

362

363

Mendoza L. 2010. Pythium insidiosum: an overview. Veterinary Microbiology 146:1-16. DOI: $10.1016 /$ j.vetmic.2010.07.019.

Grooters AM., Gee MK. 2002. Development of a nested polymerase chain reaction assay for the detection and identification of Pythium insidiosum. Journal of Veterinary Internal Medicine 16:147-152.

Grooters AM., Leise BS., Lopez MK., Gee MK., O’Reilly KL. 2002. Development and evaluation of an enzyme-linked immunosorbent assay for the serodiagnosis of pythiosis in dogs. Journal of Veterinary Internal Medicine 16:142-146.

Guindon S., Dufayard J-F., Lefort V., Anisimova M., Hordijk W., Gascuel O. 2010. New algorithms and methods to estimate maximum-likelihood phylogenies: assessing the performance of PhyML 3.0. Systematic Biology 59:307-321. DOI: 10.1093/sysbio/syq010.

Inkomlue R., Larbcharoensub N., Karnsombut P., Lerksuthirat T., Aroonroch R., Lohnoo T., Yingyong W., Santanirand P., Sansopha L., Krajaejun T. 2016. Development of an AntiElicitin Antibody-Based Immunohistochemical Assay for Diagnosis of Pythiosis. Journal of Clinical Microbiology 54:43-48. DOI: 10.1128/JCM.02113-15.

Intaramat A., Sornprachum T., Chantrathonkul B., Chaisuriya P., Lohnoo T., Yingyong W., Jongruja N., Kumsang Y., Sandee A., Chaiprasert A., Banyong R., Santurio JM., Grooters AM., Ratanabanangkoon K., Krajaejun T. 2016. Protein A/G-based 
immunochromatographic test for serodiagnosis of pythiosis in human and animal subjects from Asia and Americas. Medical Mycology 54:641-647. DOI: 10.1093/mmy/myw018.

366

367

368

369

370

371

372

373

374

375

376

377

378

379

380

381

382

383

384

Jindayok T., Piromsontikorn S., Srimuang S., Khupulsup K., Krajaejun T. 2009.

Hemagglutination test for rapid serodiagnosis of human pythiosis. Clinical and vaccine immunology 16:1047-1051. DOI: 10.1128/CVI.00113-09.

Keeratijarut A., Karnsombut P., Aroonroch R., Srimuang S., Sangruchi T., Sansopha L., Mootsikapun P., Larbcharoensub N., Krajaejun T. 2009. Evaluation of an in-house immunoperoxidase staining assay for histodiagnosis of human pythiosis. The Southeast Asian Journal of Tropical Medicine and Public Health 40:1298-1305.

Keeratijarut A., Lohnoo T., Yingyong W., Nampoon U., Lerksuthirat T., Onpaew P., Chongtrakool P., Krajaejun T. 2014. PCR amplification of a putative gene for exo-1, 3beta-glucanase to identify the pathogenic oomycete Pythium insidiosum. Asian Biomedicine 8:637-644.

Keeratijarut A., Lohnoo T., Yingyong W., Rujirawat T., Srichunrusami C., Onpeaw P., Chongtrakool P., Brandhorst TT., Krajaejun T. 2015. Detection of the oomycete Pythium insidiosum by real-time PCR targeting the gene coding for exo-1,3- $\beta$-glucanase. Journal of Medical Microbiology 64:971-977. DOI: 10.1099/jmm.0.000117.

Keeratijarut A., Lohnoo T., Yingyong W., Sriwanichrak K., Krajaejun T. 2013. A peptide ELISA to detect antibodies against Pythium insidiosum based on predicted antigenic determinants of exo-1,3-beta-glucanase. The Southeast Asian Journal of Tropical Medicine and Public Health 44:672-680. 
385 Kittichotirat W., Bumgarner RE., Asikainen S., Chen C. 2011. Identification of the pangenome

386

387

388

389

390

391

392

393

394

395

396

397

398

399

400

401

402

403

404

405

406

and its components in 14 distinct Aggregatibacter actinomycetemcomitans strains by comparative genomic analysis. PloS One 6:e22420. DOI: 10.1371/journal.pone.0022420.

Kittichotirat W., Patumcharoenpol P., Rujirawat T., Lohnoo T., Yingyong W., Krajaejun T. 2017. Draft genome and sequence variant data of the oomycete Pythium insidiosum strain Pi45 from the phylogenetically-distinct Clade-III. Data in Brief 15:896-900. DOI: 10.1016/j.dib.2017.10.047.

Krajaejun T., Chongtrakool P., Angkananukul K., Brandhorst TT. 2010. Effect of temperature on growth of the pathogenic oomycete Pythium insidiosum. The Southeast Asian Journal of Tropical Medicine and Public Health 41:1462-1466.

Krajaejun T., Imkhieo S., Intaramat A., Ratanabanangkoon K. 2009. Development of an immunochromatographic test for rapid serodiagnosis of human pythiosis. Clinical and vaccine immunology 16:506-509. DOI: 10.1128/CVI.00276-08.

Krajaejun T., Kunakorn M., Niemhom S., Chongtrakool P., Pracharktam R. 2002. Development and evaluation of an in-house enzyme-linked immunosorbent assay for early diagnosis and monitoring of human pythiosis. Clinical and Diagnostic Laboratory Immunology $9: 378-382$.

Krajaejun T., Kunakorn M., Pracharktam R., Chongtrakool P., Sathapatayavongs B., Chaiprasert A., Vanittanakom N., Chindamporn A., Mootsikapun P. 2006a. Identification of a novel 74-kiloDalton immunodominant antigen of Pythium insidiosum recognized by sera from human patients with pythiosis. Journal of Clinical Microbiology 44:1674-1680. DOI: 10.1128/JCM.44.5.1674-1680.2006. 
407 Krajaejun T., Pracharktam R., Wongwaisayawan S., Rochanawutinon M., Kunakorn M., 408 Kunavisarut S. 2004. Ocular pythiosis: is it under-diagnosed? American Journal of 409 Ophthalmology 137:370-372. DOI: 10.1016/S0002-9394(03)00908-5.

410

411

412

413

414

415

416

417

418

419

420

421

422

423

424

425

426

427

428

Krajaejun T., Sathapatayavongs B., Pracharktam R., Nitiyanant P., Leelachaikul P., Wanachiwanawin W., Chaiprasert A., Assanasen P., Saipetch M., Mootsikapun P., Chetchotisakd P., Lekhakula A., Mitarnun W., Kalnauwakul S., Supparatpinyo K., Chaiwarith R., Chiewchanvit S., Tananuvat N., Srisiri S., Suankratay C., Kulwichit W., Wongsaisuwan M., Somkaew S. 2006b. Clinical and epidemiological analyses of human pythiosis in Thailand. Clinical Infectious Diseases 43:569-576. DOI: 10.1086/506353.

Lerksuthirat T., Sangcakul A., Lohnoo T., Yingyong W., Rujirawat T., Krajaejun T. 2017. Evolution of the Sterol Biosynthetic Pathway of Pythium insidiosum and Related Oomycetes Contributes to Antifungal Drug Resistance. Antimicrobial Agents and Chemotherapy 61. DOI: 10.1128/AAC.02352-16.

Mora D., Arioli S. 2014. Microbial urease in health and disease. PLoS pathogens 10:e1004472. DOI: $10.1371 /$ journal.ppat.1004472.

Patumcharoenpol P., Rujirawat T., Lohnoo T., Yingyong W., Vanittanakom N., Kittichotirat W., Krajaejun T. 2018. Draft genome sequences of the oomycete Pythium insidiosum strain CBS 573.85 from a horse with pythiosis and strain CR02 from the environment. Data in Brief 16:47-50. DOI: 10.1016/j.dib.2017.11.002.

Pracharktam R., Changtrakool P., Sathapatayavongs B., Jayanetra P., Ajello L. 1991. Immunodiffusion test for diagnosis and monitoring of human pythiosis insidiosi. Journal of Clinical Microbiology 29:2661-2662. 
429 Rujirawat T., Patumcharoenpol P., Lohnoo T., Yingyong W., Kumsang Y., Payattikul P.,

430 Tangphatsornruang S., Suriyaphol P., Reamtong O., Garg G., Kittichotirat W., Krajaejun

431

432

433

T. 2018. Probing the Phylogenomics and Putative Pathogenicity Genes of Pythium insidiosum by Oomycete Genome Analyses. Scientific Reports 8:4135. DOI:

434 10.1038/s41598-018-22540-1.

435

Rujirawat T., Patumcharoenpol P., Lohnoo T., Yingyong W., Lerksuthirat T.,

436

437

438

439

440

441

442

443

444

445

446

447

448

449

450

451

Tangphatsornruang S., Suriyaphol P., Grenville-Briggs LJ., Garg G., Kittichotirat W., Krajaejun T. 2015. Draft Genome Sequence of the Pathogenic Oomycete Pythium insidiosum Strain Pi-S, Isolated from a Patient with Pythiosis. Genome Announcements 3. DOI: 10.1128/genomeA.00574-15.

Rujirawat T., Sridapan T., Lohnoo T., Yingyong W., Kumsang Y., Sae-Chew P., Tonpitak W., Krajaejun T. 2017. Single nucleotide polymorphism-based multiplex PCR for identification and genotyping of the oomycete Pythium insidiosum from humans, animals and the environment. Infection, Genetics and Evolution 54:429-436. DOI: 10.1016/j.meegid.2017.08.004.

Rutherford JC. 2014. The emerging role of urease as a general microbial virulence factor. PLoS pathogens 10:e1004062. DOI: 10.1371/journal.ppat.1004062.

Schurko AM., Mendoza L., Lévesque CA., Désaulniers NL., de Cock AWAM., Klassen GR. 2003. A molecular phylogeny of Pythium insidiosum. Mycological Research 107:537544.

Supabandhu J., Vanittanakom P., Laohapensang K., Vanittanakom N. 2009. Application of immunoblot assay for rapid diagnosis of human pythiosis. Journal of the Medical Association of Thailand 92:1063-1071. 
452 Thianprasit M., Chaiprasert A., Imwidthaya P. 1996. Human pythiosis. Current Topics in $453 \quad$ Medical Mycology 7:43-54.

454 Vilela R., Viswanathan P., Mendoza LA. 2015. A biochemical screening approach to putatively 455 differentiate mammalian pathogenic Oomycota species in the clinical laboratory. Journal 456 of Medical Microbiology 64:862-868. DOI: 10.1099/jmm.0.000111.

457 Witte C-P., Rosso MG., Romeis T. 2005. Identification of three urease accessory proteins that 458 are required for urease activation in Arabidopsis. Plant Physiology 139:1155-1162. DOI: $459 \quad 10.1104 /$ pp.105.070292.

460 Zanette RA., Ferreiro L., Alves SH., Jesus FPK., Lautert C., Spanamberg A., Santurio JM. 2013. 461 Enzymatic variability among Brazilian Pythium insidiosum isolates. Revista 462 Iberoamericana De Micología 30:264-266. DOI: 10.1016/j.riam.2012.12.005. 


\section{Table $\mathbf{1}$ (on next page)}

A list of 26 strains of $P$. insidiosum used for biochemical characterization in this study.

Information on strain identification numbers, sources of isolation, country of origins, assigned phylogenetic clades, rates of growth, and types of biochemical assays are provided in the table header. The symbol ' + ' and ' $(-)$ ' indicate positive and negative biochemical reaction, respectively. Fast ( $\geq 5 \mathrm{~mm} /$ day) and slow ( $<5 \mathrm{~mm} /$ day) growths are determined based on mean radial growth rate. The strains Pi07, Pi35, and Pi45 have their genome sequences available. The strains CBS574.85 and ATCC28251 are included in this and other biochemical studies (Vilela, Viswanathan \& Mendoza, 2015). 


\begin{tabular}{|c|c|c|c|c|c|c|c|c|c|c|c|c|c|c|c|c|}
\hline $\begin{array}{l}\text { 見 } \\
\stackrel{\Xi}{\mathbb{E}}\end{array}$ & 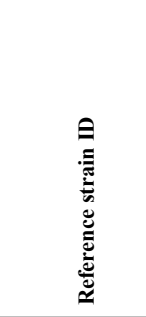 & 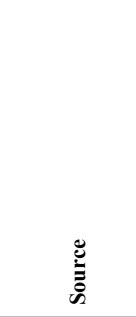 & $\stackrel{\Xi}{E}$ & 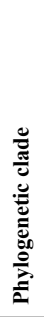 & 疍 & 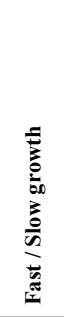 & 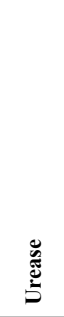 & ت્ّ & 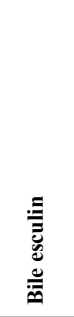 & 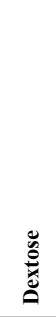 & 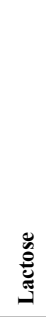 & 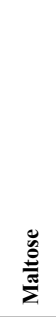 & : & 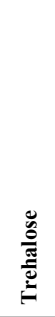 & $\frac{\ddot{\partial}}{\vec{x}}$ & 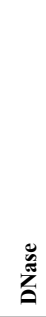 \\
\hline Pi08 & CBS580.85 & Equine & Costa Rica & I & 10.6 & Fast & + & $(-)$ & + & + & $(-)$ & + & + & + & $(-)$ & + \\
\hline Pi03 & CBS577.85 & Equine & Costa Rica & I & 10.1 & Fast & + & $(-)$ & + & + & $(-)$ & + & $(-)$ & + & $(-)$ & + \\
\hline ATCC 28251 & ATCC28251 & Equine & $\begin{array}{l}\text { Papua New } \\
\text { Guinea }\end{array}$ & II & 9.5 & Fast & $(-)$ & $(-)$ & + & + & $(-)$ & + & + & + & $(-)$ & + \\
\hline Pi10 & ATCC200269 & Human & USA & I & 9.0 & Fast & + & $(-)$ & + & + & $(-)$ & + & + & + & $(-)$ & + \\
\hline $\mathrm{Pi02}$ & CBS579.85 & Equine & Costa Rica & I & 8.4 & Fast & + & $(-)$ & + & + & $(-)$ & + & + & + & $(-)$ & + \\
\hline Pi26 & N/A & Human & Thailand & II & 8.3 & Fast & + & $(-)$ & + & + & $(-)$ & + & + & + & $(-)$ & + \\
\hline Pi36 & ATCC64221 & Equine & Australia & II & 7.9 & Fast & + & $(-)$ & + & + & $(-)$ & + & + & + & $(-)$ & + \\
\hline Pi35 & $\mathrm{Pi}-\mathrm{S}$ & Human & Thailand & II & 7.4 & Fast & + & $(-)$ & + & + & $(-)$ & + & + & + & $(-)$ & + \\
\hline Pi42 & CR02 & Environment & Thailand & II & 7.3 & Fast & + & $(-)$ & + & + & $(-)$ & + & + & + & $(-)$ & + \\
\hline Pi23 & N/A & Human & Thailand & II & 7.2 & Fast & $(-)$ & $(-)$ & + & + & $(-)$ & + & + & + & $(-)$ & + \\
\hline Pi05 & CBS575.85 & Equine & Costa Rica & I & 7.0 & Fast & + & $(-)$ & + & + & $(-)$ & + & + & + & $(-)$ & + \\
\hline Pi09 & CBS101555 & Equine & Brazil & I & 6.6 & Fast & + & $(-)$ & + & + & $(-)$ & + & + & + & $(-)$ & + \\
\hline Pi51 & $\mathrm{N} / \mathrm{A}$ & Environment & Thailand & III & 6.2 & Fast & $(-)$ & $(-)$ & + & + & $(-)$ & + & + & + & $(-)$ & + \\
\hline Pi49 & $\mathrm{N} / \mathrm{A}$ & Human & Thailand & III & 5.7 & Fast & $(-)$ & $(-)$ & + & + & $(-)$ & + & + & + & $(-)$ & + \\
\hline Pil1 & N/A & Human & Thailand & II & 5.2 & Fast & + & $(-)$ & + & + & $(-)$ & + & + & + & $(-)$ & + \\
\hline Pi19 & N/A & Human & Thailand & II & 5.1 & Fast & + & $(-)$ & + & + & $(-)$ & + & + & + & $(-)$ & + \\
\hline Pi45 & $\mathrm{MCC} 13$ & Human & Thailand & III & 5.0 & Fast & $(-)$ & $(-)$ & + & + & $(-)$ & + & + & + & $(-)$ & + \\
\hline Pi20 & CBS119455 & Human & Thailand & II & 4.6 & Slow & + & $(-)$ & + & + & $(-)$ & + & $(-)$ & + & $(-)$ & + \\
\hline Pi50 & ATCC90586 & Human & USA & III & 4.2 & Slow & $(-)$ & $(-)$ & + & + & $(-)$ & + & + & + & $(-)$ & + \\
\hline Pi07 & CBS573.85 & Equine & Costa Rica & I & 3.7 & Slow & + & $(-)$ & + & + & $(-)$ & + & + & + & $(-)$ & + \\
\hline Pi04 & CBS576.85 & Equine & Costa Rica & I & 3.7 & Slow & + & $(-)$ & + & + & $(-)$ & + & $(-)$ & + & $(-)$ & + \\
\hline Pi46 & N/A & Human & Thailand & III & 2.6 & Slow & + & $(-)$ & + & $(-)$ & $(-)$ & $(-)$ & $(-)$ & $(-)$ & $(-)$ & $(-)$ \\
\hline Pi47 & N/A & Human & Thailand & III & 2.4 & Slow & $(-)$ & $(-)$ & + & $(-)$ & $(-)$ & $(-)$ & + & $(-)$ & $(-)$ & $(-)$ \\
\hline Pi44 & CBS119454 & Human & Thailand & III & 2.1 & Slow & + & $(-)$ & + & $(-)$ & $(-)$ & $(-)$ & $(-)$ & $(-)$ & $(-)$ & + \\
\hline Pi48 & N/A & Human & Thailand & III & 1.8 & Slow & + & $(-)$ & + & + & $(-)$ & + & + & + & $(-)$ & + \\
\hline CBS574.85 & CBS574.85 & Equine & Costa Rica & I & 0.7 & Slow & + & $(-)$ & + & $(-)$ & $(-)$ & $(-)$ & $(-)$ & $(-)$ & $(-)$ & $(-)$ \\
\hline \multicolumn{7}{|c|}{$\%$ Positive read $(\mathrm{n}=26)$} & 73.1 & 0.0 & 100.0 & 84.6 & 0.0 & 84.6 & 76.9 & 84.6 & 0.0 & 88.5 \\
\hline
\end{tabular}




\section{Table 2 (on next page)}

Urease and urease accessory protein orthologous sequences identified by TBLASTN search (cut-off $E$-value $\leq-6$ ) in the genomes of $P$. insidiosum strains Pi07, Pi35 and Pi45.

The query sequences are the plant Arabidopsis thaliana urease (URE; accession number, NP_176922) and urease accessory proteins D (URED; NP_850239), F (UREF; NP_850239) and G (UREG; NP_850239). Information on phylogenetic clades, growths, urease test results, gene copy, and TBLASTN search output (i.e., E-values, identity, and similarity) of $P$. insidiosum is summarized in the table. 


\begin{tabular}{|l|c|c|c|c|}
\hline Strain & Pi07 & Pi35 & \multicolumn{2}{|c|}{ Pi45 } \\
\hline Phylogenetic clade & I & II & \multicolumn{2}{|c|}{ III } \\
\hline Growth rate (mm/day) & 3.7 & 7.4 & \multicolumn{2}{|c|}{5.0} \\
\hline Fast / Slow growth & Slow & Fast & \multicolumn{2}{|c|}{ Fast } \\
\hline Urease test & + & + & \multicolumn{2}{|c|}{$(-)$} \\
\hline Gene copy & Copy-1 & Copy-1 & Copy-1 & Copy-2 \\
\hline URE & & & & \\
\hline E-value & 0.0 & 0.0 & 0.0 & 0.0 \\
\hline Identity (\%) & 64 & 63 & 64 & 64 \\
\hline Similarity (\%) & 75 & 73 & 75 & 76 \\
\hline URED & & & & \\
\hline E-value & $3 \mathrm{E}-19$ & $2 \mathrm{E}-16$ & $5 \mathrm{E}-26$ & $2 \mathrm{E}-18$ \\
\hline Identity (\%) & 42 & 42 & 31 & 47 \\
\hline Similarity (\%) & 60 & 58 & 52 & 67 \\
\hline UREF & & & & \\
\hline E-value & - & $1 \mathrm{E}-53$ & $3 \mathrm{E}-54$ & $6 \mathrm{E}-52$ \\
\hline Identity (\%) & - & 42 & 42 & 40 \\
\hline Similarity (\%) & - & 61 & 61 & 59 \\
\hline UREG & & & & \\
\hline E-value & 64 & 87 & 89 & 64 \\
\hline Identity (\%) & & $6 \mathrm{E}-60$ & $5 \mathrm{E}-39$ & $2 \mathrm{E}-33$ \\
\hline Similarity (\%) & & 73 & 74 & 56 \\
\hline
\end{tabular}

1 


\section{Figure 1}

The Oomycete Gene Table demonstrating the identified gene clusters containing the urease- and urease accessory protein-encoding genes presented in the genomes of $P$. insidiosum (arrow head), 19 related oomycetes, and two diatoms (asterisks).

Cluster identification numbers (Cluster ID), function annotations, and identities of the genomes are shown in the table header. The arrow head indicates the genome of $P$. insidiosum. A gray box represents a similar sequence is identified, while a black box represents no similar sequence is found, in any given genome. Colored boxes refer to gene copy number.

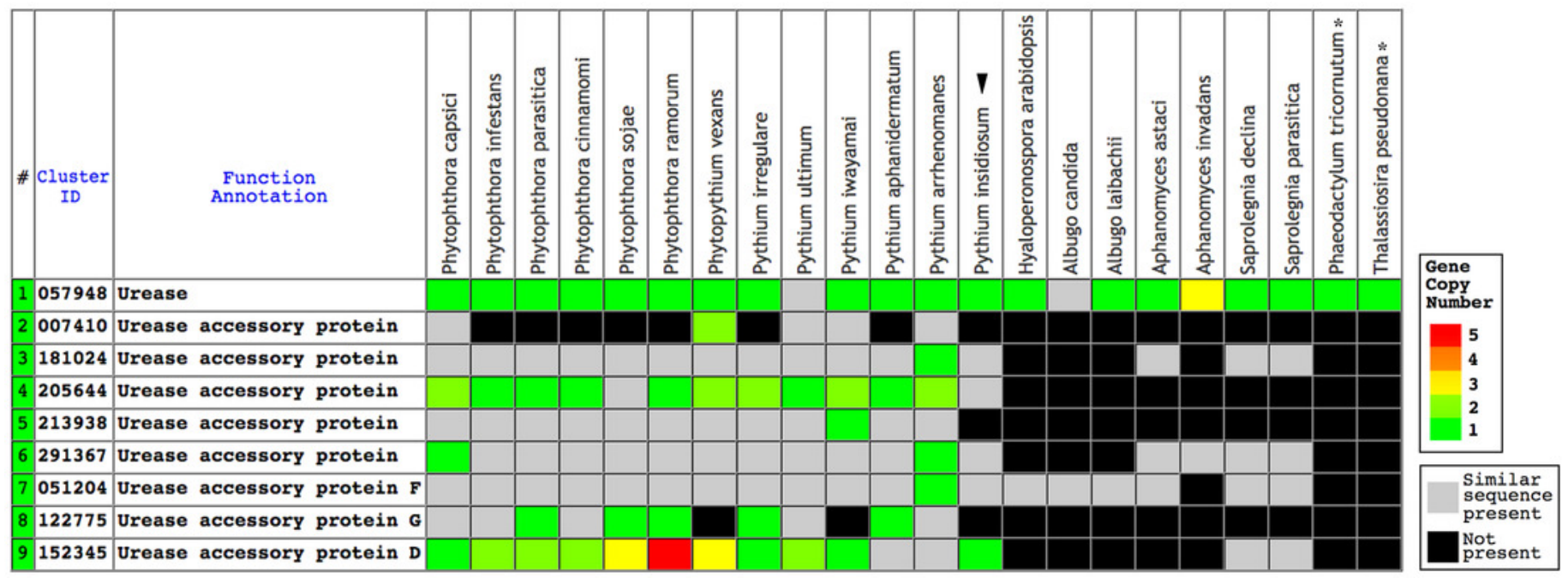




\section{Figure 2}

Biochemical assays of four representative strains of $P$. insidiosum.

Strain Pi05 (A) at the day of inoculation (Day\#0; the colors of all agars remain unchanged), and strains Pi02 (B), ATCC 28251 (C) and CBS 574.85 (D) at 2 days post-inoculation (Day\#2; biochemical results are read). Ten routinely-available biochemical agars are included in this study: urea agar (Ure), Simmons'citrate agar (Cit), Bile esculin agar (Bil), DNA agar (DNA), and purple agar base with dextrose (Dex), lactose (Lac), maltose (Mal), sucrose (Suc), trehalose (Tre) or xylose (Xyl). The symbols ' + ' and '(-)' indicate positive and negative biochemical reaction, respectively. (The source credit for the photographs: Teerat Kanpanleuk) 
A.

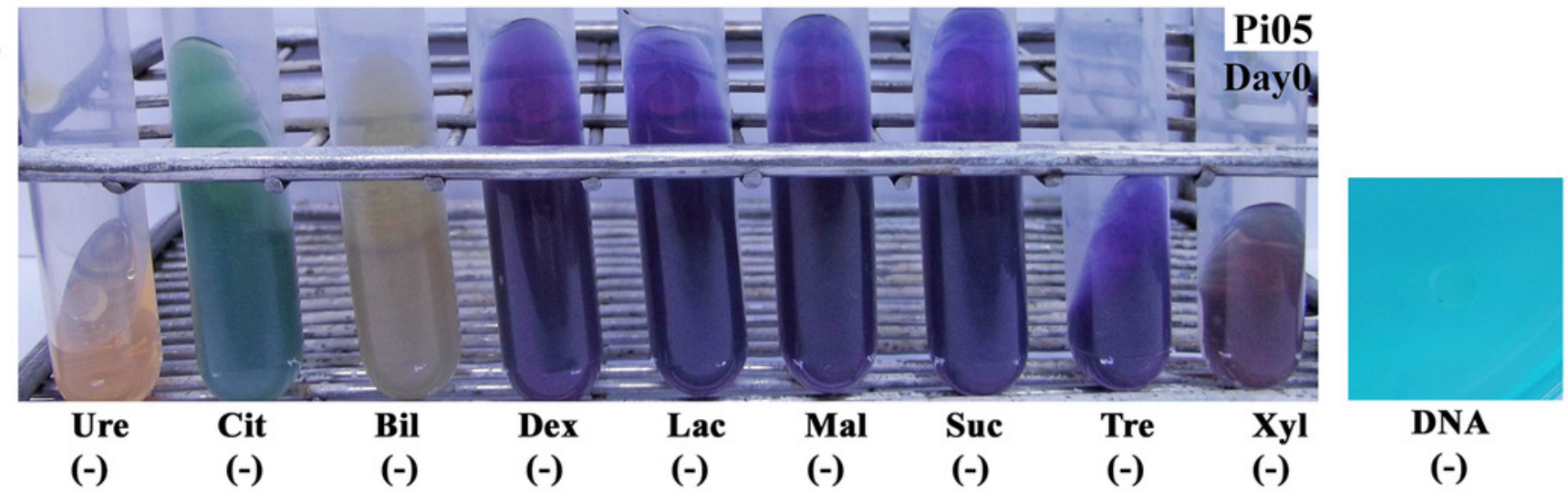

B.

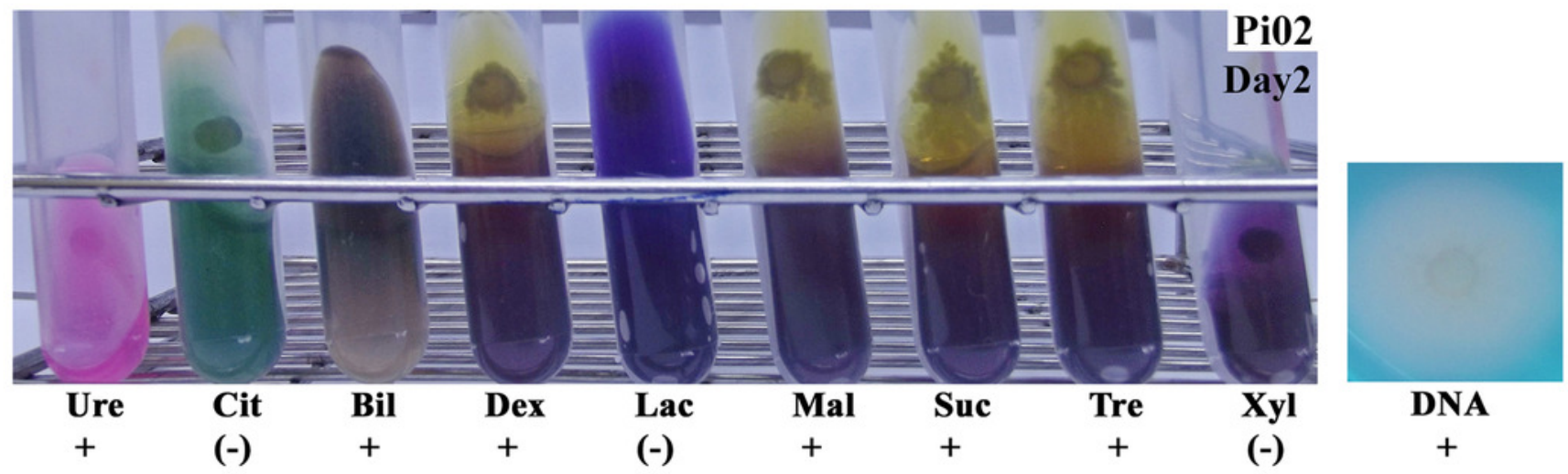

C.

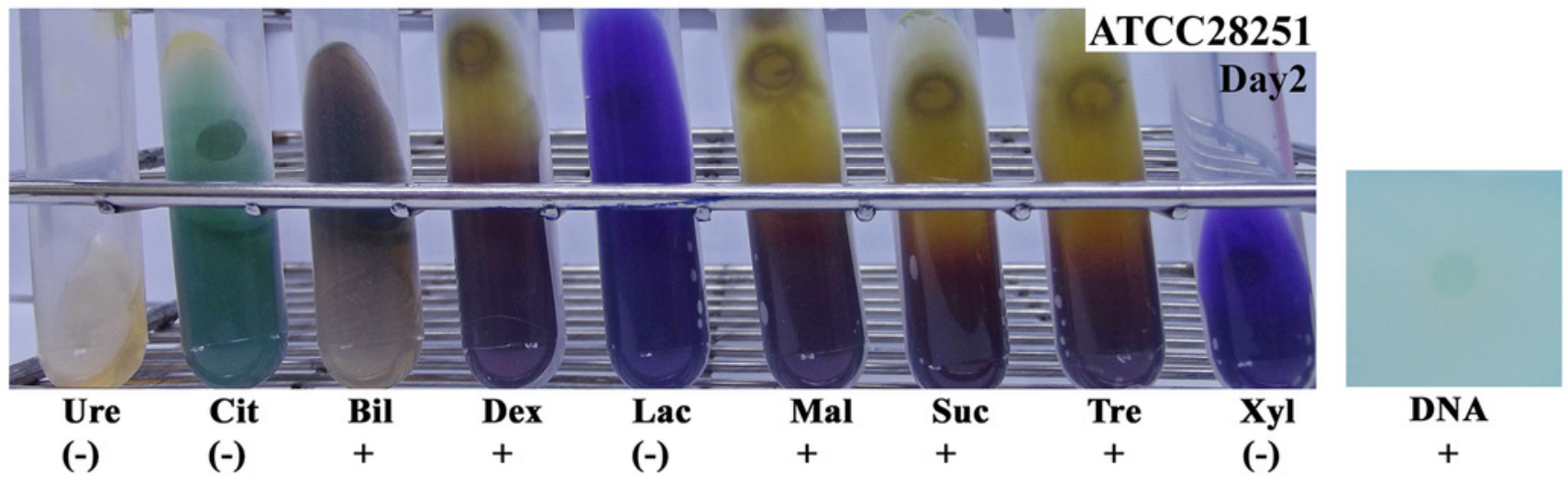

D.

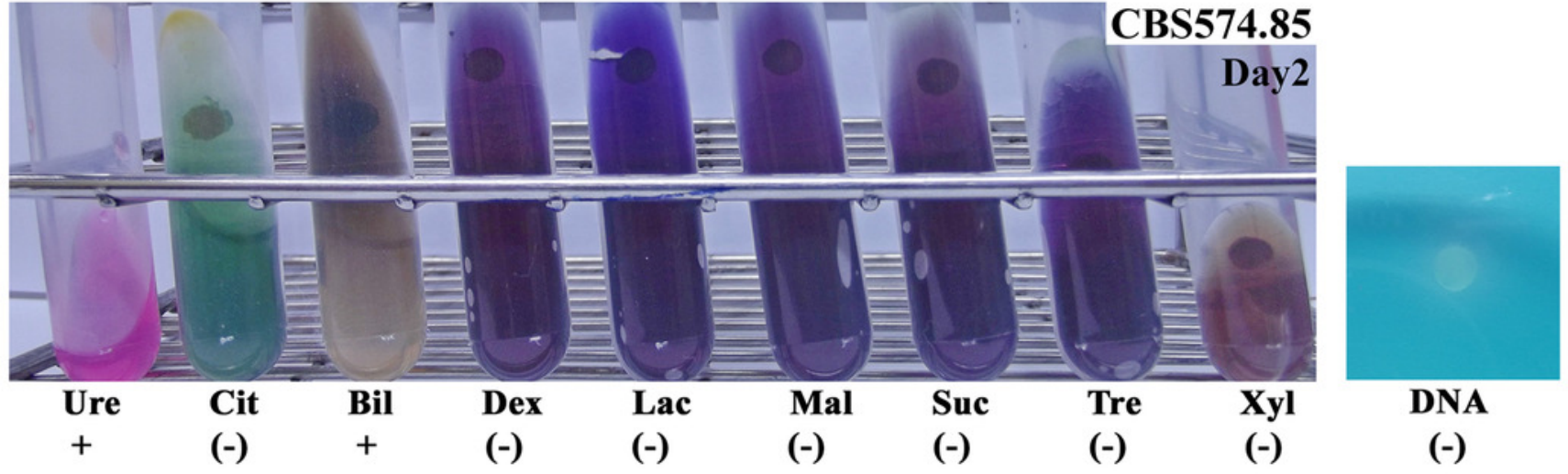




\section{Figure 3}

Sequence alignment of full-length deduced urease proteins from $P$. insidiosum, related oomycetes, and diatoms.

Initials of the genus and species names of each organism (Table S1) are listed on the left. The open box indicates $P$. insidiosum. The asterisks represent the diatoms. The symbol ' - ' indicates an absent amino acid in any given sequence. Cyan and gray colors highlight the identical and similar amino acids, respectively. 


\begin{tabular}{|c|c|}
\hline & \\
\hline Sa_dec & $----k e S 1 I p m D g D--v V L$ \\
\hline & 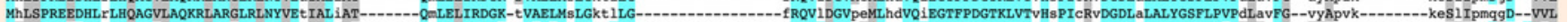 \\
\hline Ap_ast & --1RQVMDGVSAML hdVQVEGTFPDGTKLVTVHSPICRVDGDLaLALYGSFLPiPALDSFG--PAdppftgh-----ddqImv1DDakGIeL \\
\hline Ap inv 3 & --1RQVMDGVSAML hdVQVEGTFPDGTKLVTVHNPICRVDGDMSLALYGSF fPVPSLESFG--PAePSVdL- \\
\hline Ap-inv1 & -1RQVMDGV SAML LdVQVEGTFPDGTKLVTVHNPICRVDGDMSLAL YGSF fPVPSLBSFG--PAepsvdL. \\
\hline Ap inv2 & GVSAML hdVQVEGTFPDGTKLVTVHNPICRVDGDMSLALYGSFFPVPSLESFC \\
\hline$\frac{\text { Ap_Lnve }}{\mathrm{Py} \text { ing }}$ & 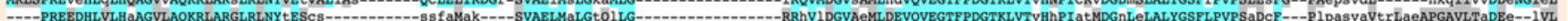 \\
\hline Hy ara & 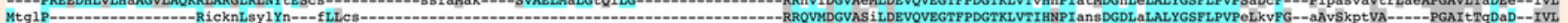 \\
\hline Py_irr & 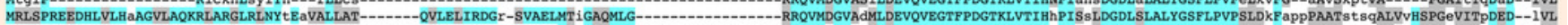 \\
\hline Py_iwa & \\
\hline $\mathrm{Ph}$ vex & MRLSPREEDHLVLHaAGaẼAQKRLARGLRLNYsËaVALLAaqvVIr1dQVLEYIRDGK-tVAEL \\
\hline $\mathrm{Ph}$ - inf & MRLSPREEEHLMLHTAGALAQKRLARG \\
\hline Ph_par & MRLSPREESHLMLHTAGALAQKRLARGLRLNYSESVALLAT-------QVLELIRDGK-tVAELMTLGAQMLG- \\
\hline Ph_ram & -RRQVMeGVAS ILDEVQVEGTFPDGTKLVTIHNPISNLLDGDLSLAL YGSFLPVPKLEVFG--sPATt Ta \\
\hline Ph_cin & 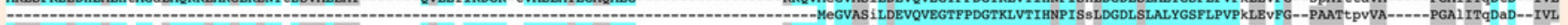 \\
\hline Ph_soj & MLHSAGELAOKRLARGLRLNYTESVALLAT-..--.- \\
\hline Py_arr & PIatMDGDLSLALYGSFLPV \\
\hline aph & \\
\hline & HLqLHQVGrLAQYRLARGVRLNY \\
\hline
\end{tabular}

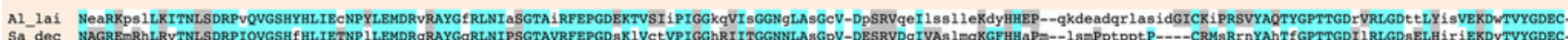

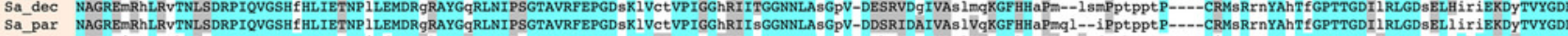

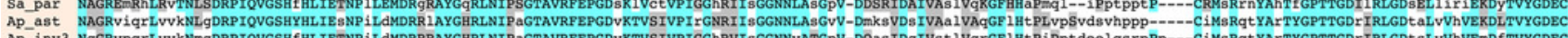

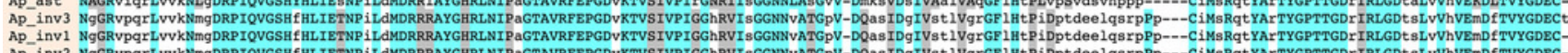

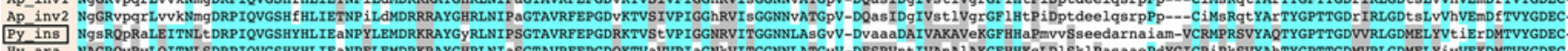

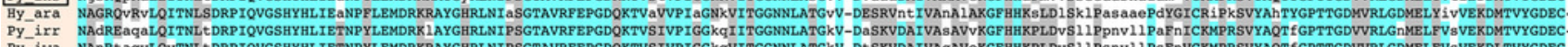

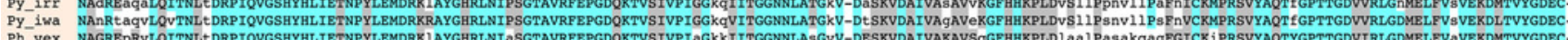

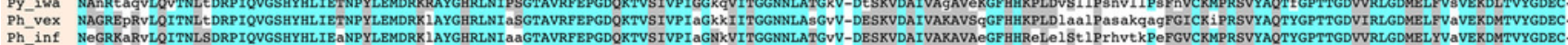

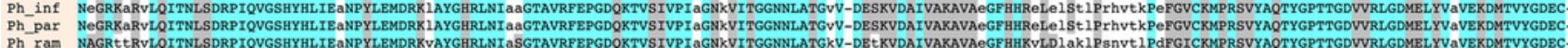

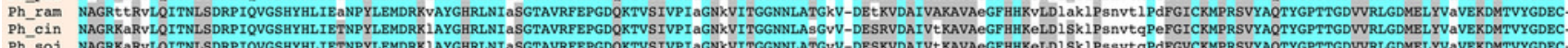

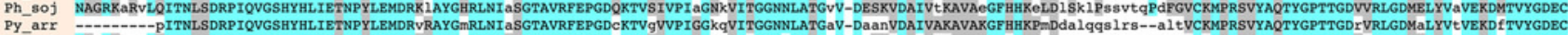

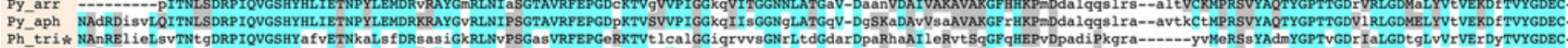

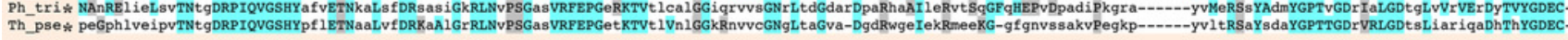

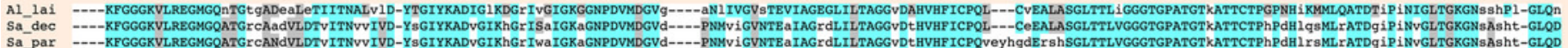

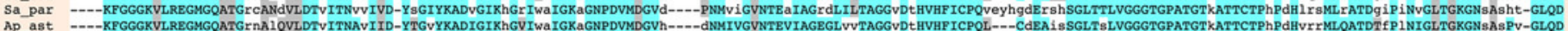

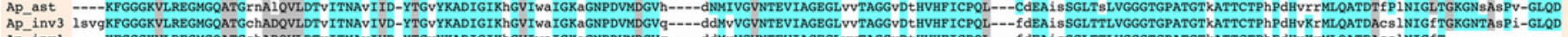

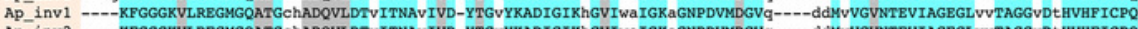
Ap inV2 ----KFGGGKVLREGMGQATGChADQVLDTVITNAVTVD-YTGVYKADIGIKhGVIWaIGKaGNPDVMDGVq-----ddHWVGVWTEVIAGEGLVVTAGGVDTHVHFICPQI--

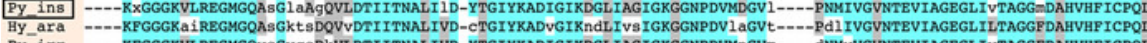

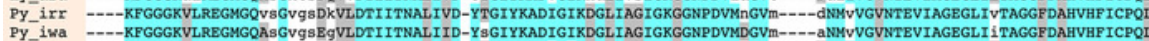

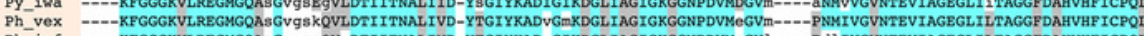

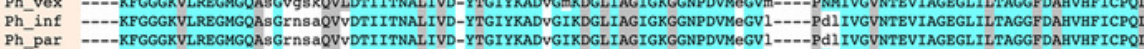
Ph_ram ----KFGGGKVLREGMGQAsGktsaQVVDTIITNALIID-YTGIYKADVGIKDGLIAGIGKGGNPDVNEGVV----PN1IVGVNTEVIAGEGLILTAGGPDAHVHFICPQI-I

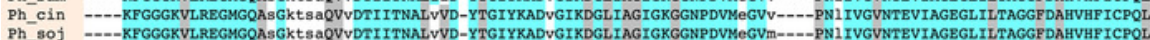

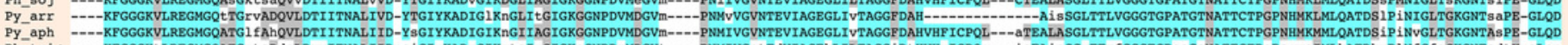

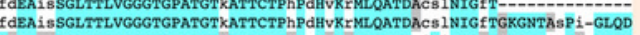
-CTEALASGLTTLVGGGTGPATGTNATTCTPGPAHMKLMLQATDVIPINIGLTGKGNTSMPE-GLQD CTEALASGLTTLVGGGLGPTGTNATTCTPGPNHMKLMLOATDS FPMNIGLTGKGNTAMPE-GLQD CTEALASGLTTLVGGGTGPATGTNATTCTPGPNHMKLMLQATDS FPMNIGLTGKGNTAMPE-GLQD CTEALAAGLTCLVGGGTGPATGTNATTCTPGPNHMKLMLOATDS IPMNIGFTS KGNTS1PE-GLOD
CTEAL SSGLTTLVGGTGPATGTNATTCTPGPNH IKMMLOATDSTPMNIGLTSKGNT IPE-GLQD CTEALASGLTTLVGGTGPATGTNATTCTPGPNHMKLMLOATDSSPMNIGLTSKGNTAIPE-GLOD CTEALASGLTTLVGGGTGATGTNATTCTPGPNHMKLMLQATDSSPMNIGLTSKGNTS1PE-GLQD

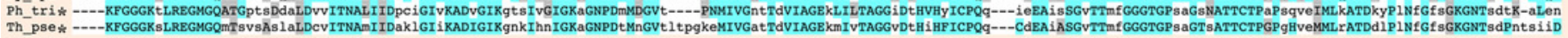

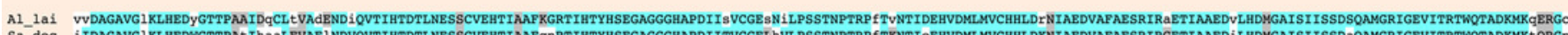

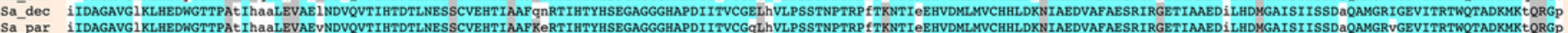

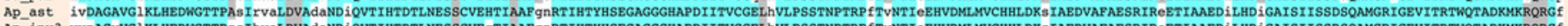

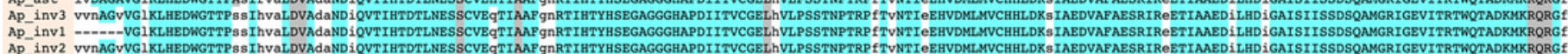

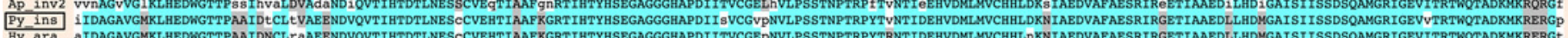

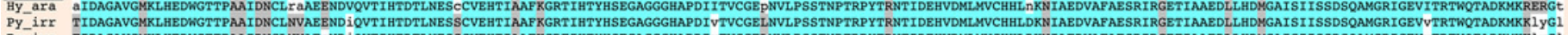

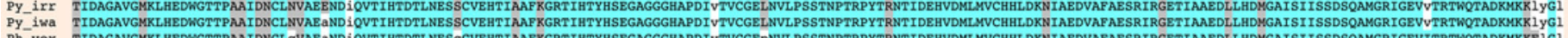

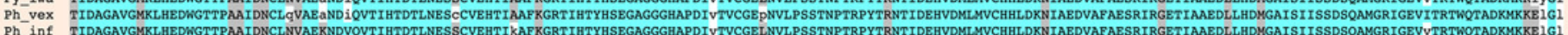

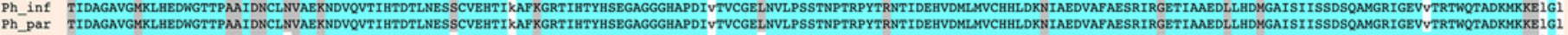

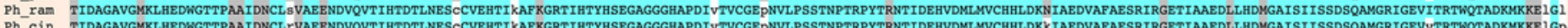

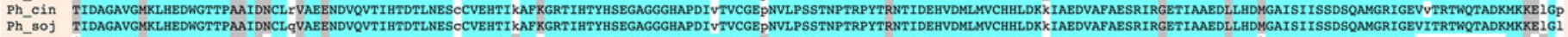

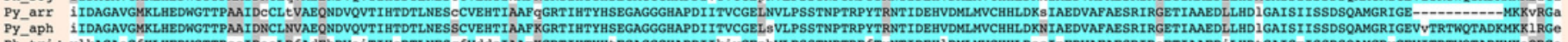

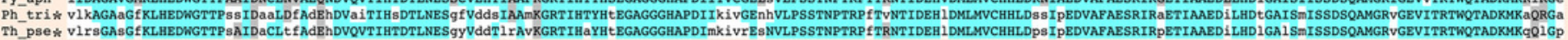

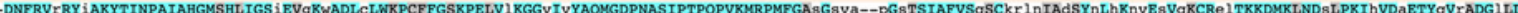

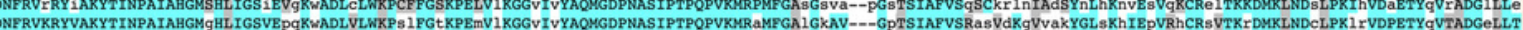

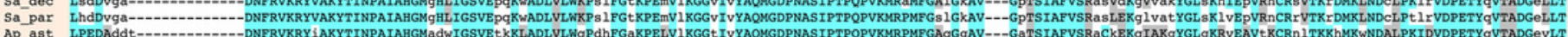
Ap_ast LPEDAddt----------DNFRVKRY IAKYTINPAIAHGMadWIGSVE KKLLADLVLNqPdhFGaKPELV1KGGt IVYAQMGDPNASIPTPQPVKMRPMFGAqGgAVAp_inv3 LPEDAetËt--------DN1RVKRY iAKYTINPAIAHGMadWIGSVEV $K$ KLADLVLNGPdhFGaKPELVIKGGS IVY SQMGDPNASIPTPQPVIMRPMFGAnGRAV

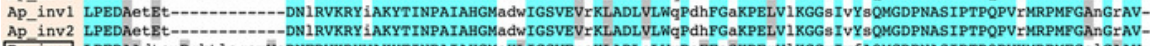

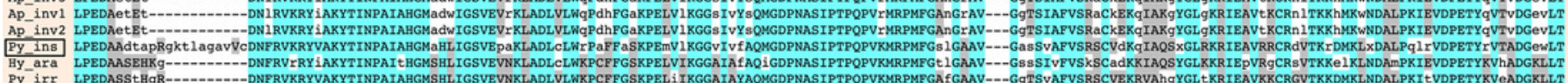

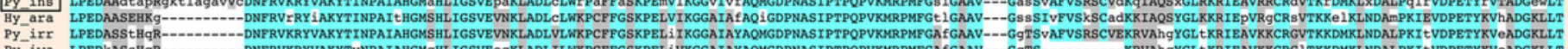

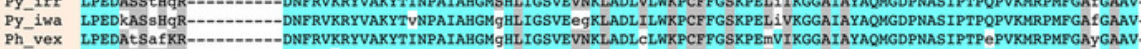

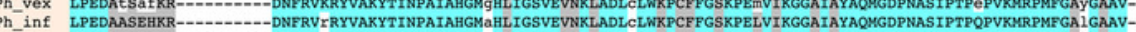
Ph_par LPEDAASEHKR------DNFRVIRYVAKYTINPAIAHGMaHLIGSVEVNKLADLCLNKRCFFGSKPELVIKGGAIAYAQMGDPNASIPTPQPVVKMRPMFGA1GANV-

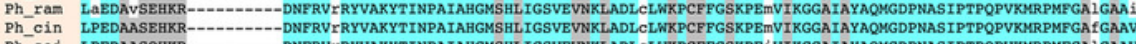

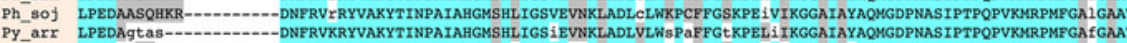

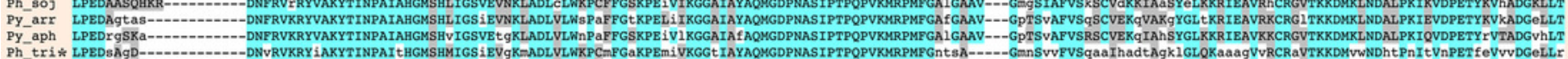

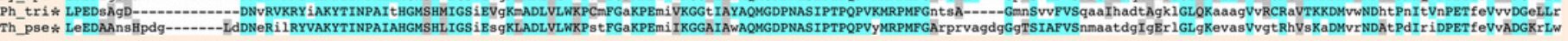




\section{Figure 4}

Maximum-likelihood phylogenetic tree reconstructed from a set of 24 urease-encoding sequences identified in the genomes of $P$. insidiosum, related oomycetes, and diatoms (outgroup; as indicated by asterisks).

The oomycete ureases can be allocated in three phylogenetically-distinct clades: (i) the clade of Pythium, Phytophthora, Phytopythium and Hyaloperonospora species; (ii) the clade of Aphanomyces and Saprolegnia species; and (iii) the clade of Albugo species. Most of the organisms contain one copy of the urease-encoding gene, except $A$. invadans (three copies) and $P$. insidiosum strain Pi45 (two copies). The red box encompasses the urease sequences from 3 representative strains of $P$. insidiosum. Only branch support values $\geq 70 \%$ are shown at the nodes. The bottom bar reveals nucleotide substitution per site. 


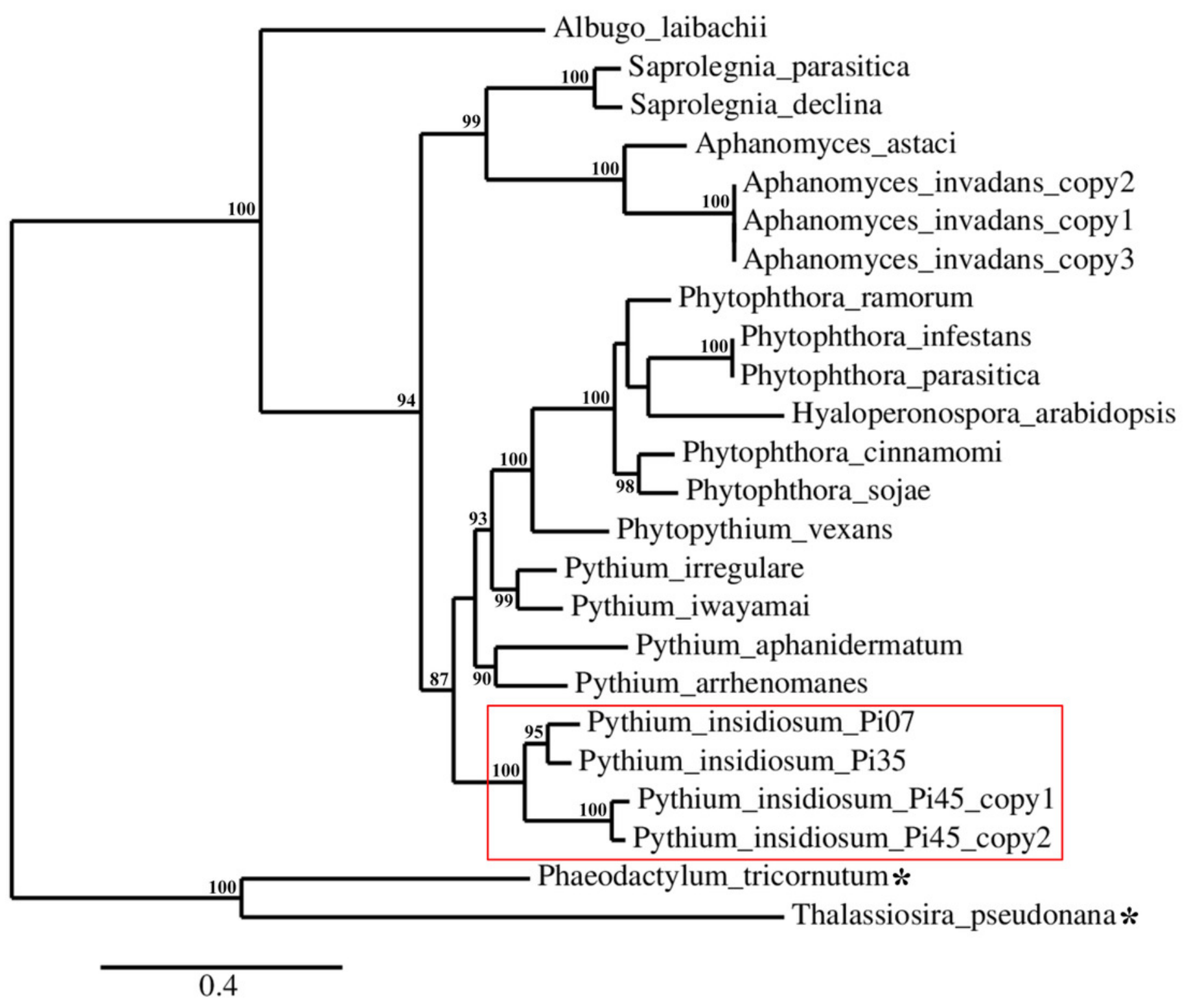

